\title{
Alat Pengukur Suhu Tubuh Non Kontak
}

\author{
Supriyanto ${ }^{1}$, Sri Wahyuning*2 \\ Program Studi D-III Teknik Elektromedik, Universitas Widya Husada Semarang, Indonesia
}

\section{INFO ARTIKEL}

Alamat Web Artikel:

https://journal.umy.ac.id/index.php/

$\mathrm{mt} /$ article/view/12499

DOI:

https://doi.org/10.18196/mt.v3i1.12499

\section{Data Artikel:}

Diterima:

07 Agustus 2021

Direview:

30 Agustus 2021

Direvisi :

29 September 2021

Disetujui :

01 Oktober 2021

Korespondensi:

wahyuning2803@gmail.com

\begin{abstract}
ABSTRAK
Penelitian ini dilakukan untuk mendeteksi secara dini paparan virus corona melalui suhu tubuh manusia. Salah satu tanda terpaparnya adalah suhu tubuh melebihi 38 derajat Celcius, meski tidak semuanya menunjukkan gejala, bahkan ada yang tergolong orang tanpa gejala (OTG). Pengukuran suhu tubuh saat ini menggunakan Thermo gun dengan mengarahkan ke dahi pada jarak 3-5 sentimeter sehingga petugas cukup dekat dengan objek. Akibatnya, pengukuran ini tidak sesuai dengan aturan protokol kesehatan terkait social distancing. Petugas berpotensi tertular dan menularkan virus Covid 19. Penelitian ini bertujuan untuk merancang alat pengukur suhu tubuh manusia dengan jarak pengukuran yang lebih jauh. Peneliti menggunakan sensor radiasi infra merah untuk mendapatkan refleksi pada objek untuk menghitung suhu dari refleksi. Oleh karena itu, teknologi mikrokontroler digunakan untuk melakukan pemrosesan data yang cepat. Selain itu mikrokontrolernya cukup kecil, sehingga alat menjadi ringan. Praktiknya sensor infra merah dapat memindai panas tubuh manusia dari jarak 50 sentimeter. Pada saat yang sama, mikrokontroler menghitung nilai suhu dan layar LCD digunakan untuk menampilkan data. Jarak efektif pengukuran dengan alat ini adalah 40-55 sentimeter, dengan akurasi pengukuran suhu 97,99\%. Sedangkan pengukuran dilakukan di tempat terbuka, tanpa AC, dan tidak terkena sinar matahari langsung.
\end{abstract}

Kata Kunci: Covid 19, Arduino, Suhu, Sensor Thermal

\section{ABSTRACT}

This research was carried out to detect early exposure to the coronavirus through human body temperature. One of the signs of exposure is the body temperature exceeding 38 degrees Celsius, although not all signify symptoms, and some even belong to asymptomatic people (OTG). The current body temperature measurement uses a Thermo gun by directing it to the forehead at a distance of 3-5 centimeters so that officers are quite close to the object. As a result, this measurement is not in accordance with the health protocol rules regarding social distancing. The officers may contract and spread the Covid 19 virus. This research aimed to design a human body temperature measuring device with a longer measurement distance. Researchers used infrared radiation sensors to get reflections on objects to calculate the temperature from the reflections. Accordingly, microcontroller technology was used to do fast data processing. Also, the microcontroller is quite small, so the tool becomes lightweight. In practice, infrared sensors can scan human body heat from a distance of 50 centimeters. At the same time, the microcontroller calculates the temperature value and the LCD screen is used to display the data. The effective measurement distance with this tool is 40-55 centimeters, with a temperature measurement accuracy of 97.99\%. Meanwhile, the measurement was conducted in the open, without air conditioning, and not exposed to direct sunlight.

Keywords: Covid 19, Arduino, Temperature, Thermal Sensor 


\section{PENDAHULUAN}

Penyebaran virus covid 19 hampir ke seluruh dunia, penularan virus covid 19 sangat cepat dan merupakan pandemi covid 19. Badan kesehatan dunia World Health Organization (WHO) melaporkan tingkat penularan covid 19 yang sangat cepat dan tingkat kematian yang mengkhawatirkan [1]. Wabah ini menular kemanusia tidak memandang kasta, suku, agama dan kedudukan. Penularan virus ini cukup tinggi, yaitu melalui kontak dengan pasien atau melalui udara. Pasien covid 19 mempunyai gejala suhu panas tinggi, sakit tenggorokan, diare, mual dan sesak nafas [2].

Sebagian pasien tidak melalui gejala tersebut karena mempunyai imunitas tubuh yang sangat baik. Pasien yang tidak mempunyai gejala tersebut dikelompokkan dengan orang tanpa gejala (OTG), pasien ini sangat menghawatirkan karena dapat menular kepada yang lain tanpa disadari. Pasien yang mempunyai riwayat penyakit bawaan mempunyai resiko kematian yang cukup tinggi daripada pasien tanpa penyakit penyerta [3]. Melihat tingginya risiko yang ditimbulkan akibat covid 19 dan penyebarann kasusnya yang sangat cepat maka diperlukan upaya mendeteksi dini, salah satunya dengan mengukur suhu tubuh.

Pasien dengan gejala suhu panas tinggi dapat dideteksi dengan rabaan tangan biasa untuk membedakan suhu normal dan suhu yang lebih tinggi, akan tetapi cara tersebut kurang akurat. Untuk memperoleh hasil yang akurat diperlukan alat pengukur tubuh atau termometer. Termometer yang umumnya digunakan pada saat ini berupa thermometer kontak yang cara penggunaannya harus menempel pada tubuh manusia. Selain termometer kontak ada termometer non kontak atau thermogun yang jarak alat dengan yang diukur antara 3 sampai 5 centimeter. Hal ini akan rawan terjadinya penularan dari satu orang ke orang lain karena terdapat kontak alat dengan orang yang diukur atau karena jaraknya cukup dekat dengan yang diukur. Untuk itu diperlukan alat yang dapat digunakan untuk mengukur dengan jarak yang cukup jauh antara pengukur dan orang yang diukur.

Penelitian ini bertujuan merancang alat pengukur suhu tubuh manusia dengan jarak antara 0.5 sampai 2 meter yang dapat meminimalisir penularan serta dapat mendeteksi suhu tubuh orang yang mengalami demam (hipertermi) yang merupakan salah satu gejala terinfeksi virus covid 19.

\section{METODE PENELITIAN}

Penelitian rancang banguan ini menggunakan mikrokontroler Arduino Uno, Arduino Uno merupakan IC (Integrated Circuit) yang menyerupai komputer mini sebagai pemrosesnya, terdiri dari perangkat keras dan perangkat lunak [4]. Memanfaatkan prosesor ini mampu mengolah inputan sensor panas menjadi tegangan listrik kemudian dikonversi menjadi sinyal digital kemudian diolah menjadi nilai angka dan dikonversi ke derajat celsius oleh mikrokontroler Arduino Uno [5]. Dengan menggunakan mikrokontroler memiliki keuntungan tidak terlalu banyak memerlukan komponen elektronika karena hasil masukan yang diperoleh dihitung menggunakan program. Berbeda dengan rancangan yang dilakukan oleh Sudimanto dimana rancangannya berupa thermometer digital tanpa menggunakan mikrokontroler sehingga Analog Digital Converter (ADC) untuk mengubah data analog menjadi data digital [6].

Untuk membuat alat pengukur suhu tubuh non kontak ini penulis menggunakan sensor thermal infra merah MLX90614. Sistem kerja sensor ini yaitu memindai dengan cara memancarkan sinar infra merah ke objek kemudian memantulkan kembali ke sensor. Hasil penelitian Pauliano dan Sumanto (2014) yang menguji rancangan alat pengukur suhu tubuh non kontak dengan sensor thermal infra merah MLX90614 yang dipadukan dengan Arduino Uno memiliki nilai akurasi 0,37 dengan membandingkan dengan thermometer digital [7]. Hasil penelitian lain yang dilakukan oleh Mukhammad dan Hyperastuty menunjukkan hasil bahwa sensor MLX90614 memiliki akurasi yang baik untuk mengukur suhu benda maupun suhu tubuh manusia secara non kontak. Pada hasil uji cobanya diperoleh prosentase eror yang diperoleh sebesar 2,8 \%. Selain itu waktu sampling suhu yang diperlukan sensor MLX90614 juga sangat cepat yaitu dalam ms untuk memperoleh hasilnya [8].

Langkah-langkah yang digunakan untuk merencanakan pembuatan alat pengukur suhu tubuh manusia non kontak berbasis mikrokontroller sebagai berikut: 


\section{Supriyanto, Wahyuning}

Alat Pengukur Suhu Tubuh Non Kontak

a. Merancang blok diagram dan wiring diagram modul sesuai dengan cara kerja alat yang dibuat.

b. Membuat modul sesuai dengan wiring diagram yang telah dibuat.

c. Membuat koding sesuai dengan tujuan alat.

d. Melakukan pengujian terhadap modul yang telah dibuat.

Blok diagram dalam proses pembuatan alat ini dibagi dalam kelompok bagian berfokus pada hal-hal yang diperlukan dan tidak melenceng dari tujuan awal pembuatan alat. Blok diagram ini ada 4 kelompok bagian yang mempunyai tugas masing-masing berikut ini:

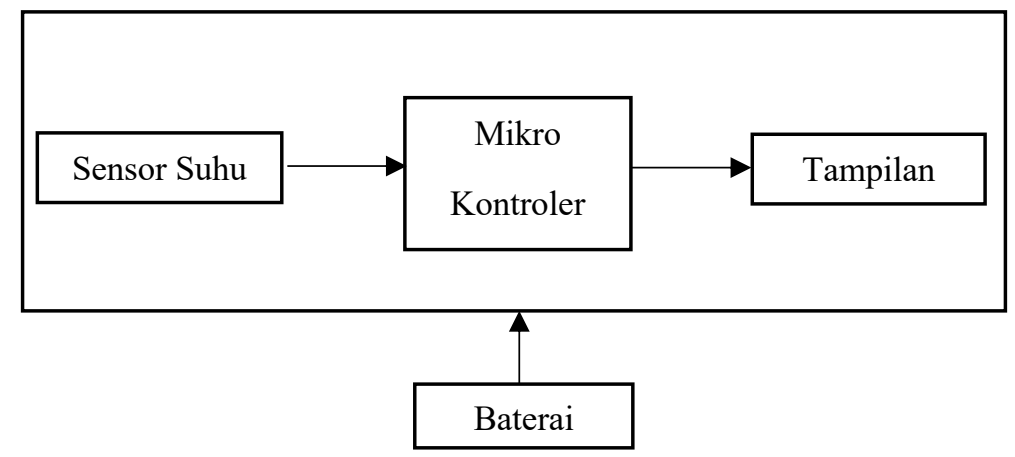

Gambar 1. Blok Diagram Pembuatan Alat

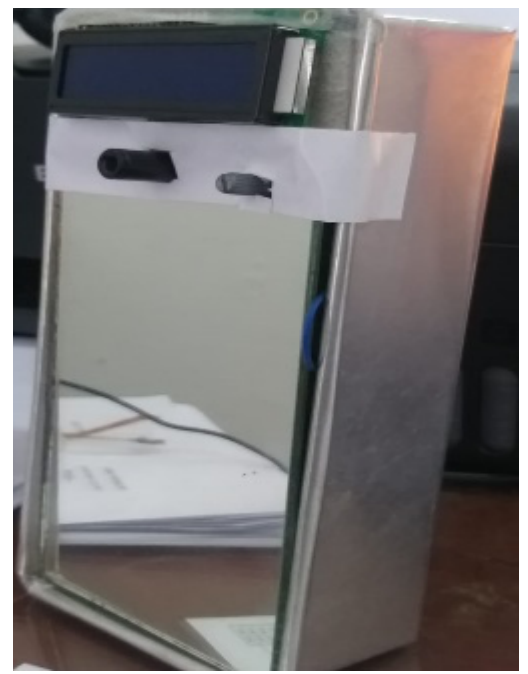

Gambar 2. Foto Alat Pengukur Suhu Non Kontak

Baterai lithium 9 Volt berfungsi sebagai sumber tegangan ke setiap rangkaian. Sensor suhu sebagai pendeteksi suhu tubuh yang dikirimkan ke mikrokontroler. Mikrokontroler Arduino Uno mengolah data yang diterima dari sensor suhu dijadikan derajad selsius dan hasil ditampilkan pada display dengan 3 kriteria.

Koding dibuat dengan bahasa c++ versi Arduino, untuk mefungsikan sensor mlx90614 DCI ini menggunakan library Adafruit_MLX90614.h yang disediakan oleh perusahaan pembuat sensor [9]. Bagian koding membaca $\mathrm{mlx} 9014$ sho=(float)mlx.readObjectTempC(): variabel float sho mendapat nilai derajad selsius.

\section{HASIL DAN PEMBAHASAN}

Hasil pengukuran suhu dilakukan membandingkan dengan alat thermo buddy buatan HuBDIC CO, LTD dengan mencarai jarak efektif pengukuran berikut ini: 


\section{Supriyanto, Wahyuning}

Alat Pengukur Suhu Tubuh Non Kontak

Tabel 1. Hasil Pengukuran

\begin{tabular}{|c|c|c|c|}
\hline No ukur & Jarak Cm & Nilai alat & Pembanding \\
\hline 1 & 20 & 33.5 & 36.5 \\
\hline 2 & 30 & 33 & 36.5 \\
\hline 3 & 40 & 32.4 & 36.5 \\
\hline 4 & 50 & 32.4 & 36.5 \\
\hline 5 & 60 & 32.2 & 36.5 \\
\hline 6 & 70 & 30.5 & 36.5 \\
\hline 7 & 80 & 29.8 & 36.5 \\
\hline
\end{tabular}

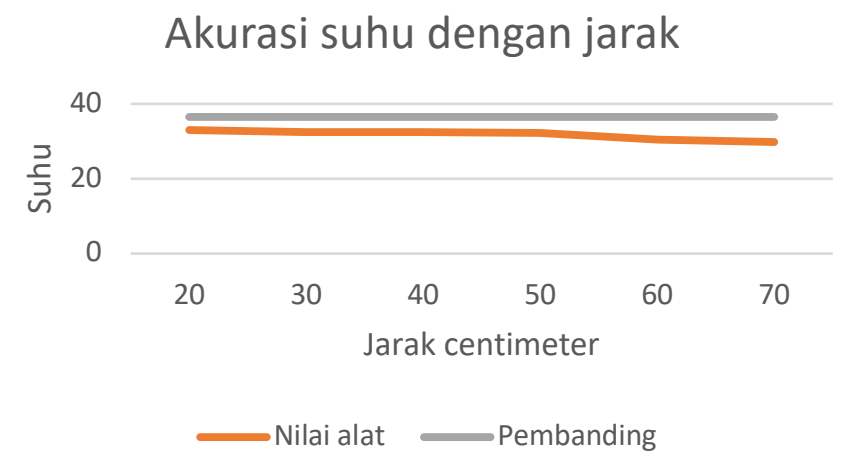

Gambar 3. Grafik Akurasi Suhu

Pengukuran nilai suhu dengan alat yang paling mendekati adalah jarak 40 samapai 50 sentimeter dan dengan selisih 4 untuk 4 derajad celsius. Nilai ukur suhu alat yang mendekati ditambah 4 sehingga kalibrasi alat dalam koding ditambah dengan nilai 4 , kodingnya sebagai berikut; $s h o=($ float $) m l x$. readObjectTempC()+4, berikut hasil pengukuran setelah dikalibrasi,

Tabel 2. Hasil Pengukuran Penyesuaian

\begin{tabular}{|c|c|c|c|}
\hline No ukur & Jarak Cm & Nilai alat & Pembanding \\
\hline 1 & 20 & 37.6 & 36.5 \\
\hline 2 & 30 & 37.1 & 36.5 \\
\hline 3 & 40 & 36.4 & 36.5 \\
\hline 4 & 50 & 36.4 & 36.5 \\
\hline 5 & 60 & 36.1 & 36.5 \\
\hline 6 & 70 & 34.3 & 36.5 \\
\hline 7 & 80 & 33.4 & 36.5 \\
\hline
\end{tabular}

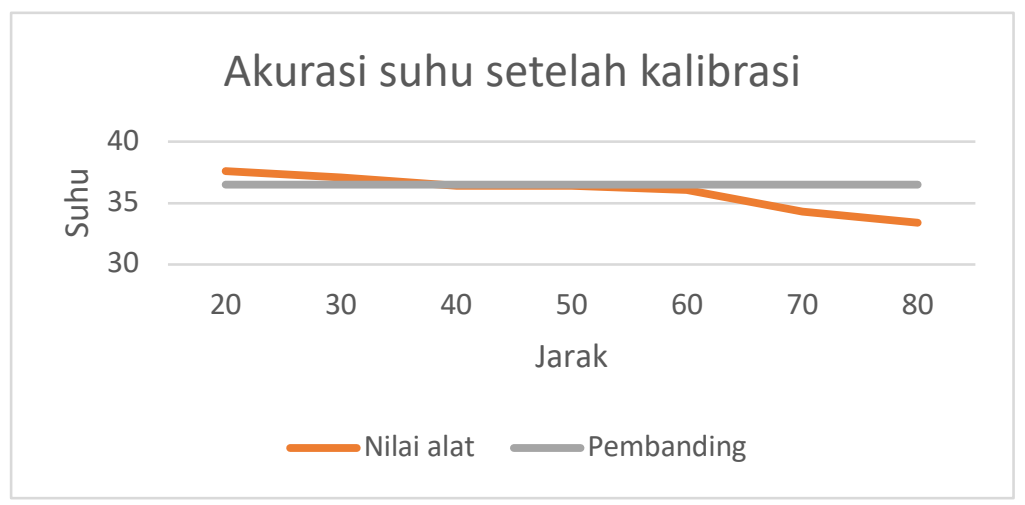

Gambar 4. Akurasi Suhu Setelah Kalibrasi

Medika Teknika : Jurnal Teknik Elektromedik Indonesia, Vol 03 No. 1, Oktober $2021 \mid 4$ 


\section{Supriyanto, Wahyuning}

Alat Pengukur Suhu Tubuh Non Kontak

Jarak efektif alat ini adalah 40-55 centimeter sehingga pengukuran berikutnya adalah menggunakan jarak 40-55 centimeter dengan hasil berikut ini:

Tabel 3. Nilai Suhu Tubuh Jarak Efektif

\begin{tabular}{|c|c|c|c|}
\hline No ukur & Suhu & Nilai alat & Prosentasi kesalahan \\
\hline 1 & 30 & 30.2 & $0,66 \%$ \\
\hline 2 & 33 & 33.1 & $0,30 \%$ \\
\hline 3 & 36 & 36 & $0 \%$ \\
\hline 4 & 37 & 37.2 & $0,54 \%$ \\
\hline 5 & 38 & 38 & $0 \%$ \\
\hline 6 & 39 & 39.1 & 0,25 \\
\hline 7 & 40 & 40.1 & 0,25 \\
\hline
\end{tabular}

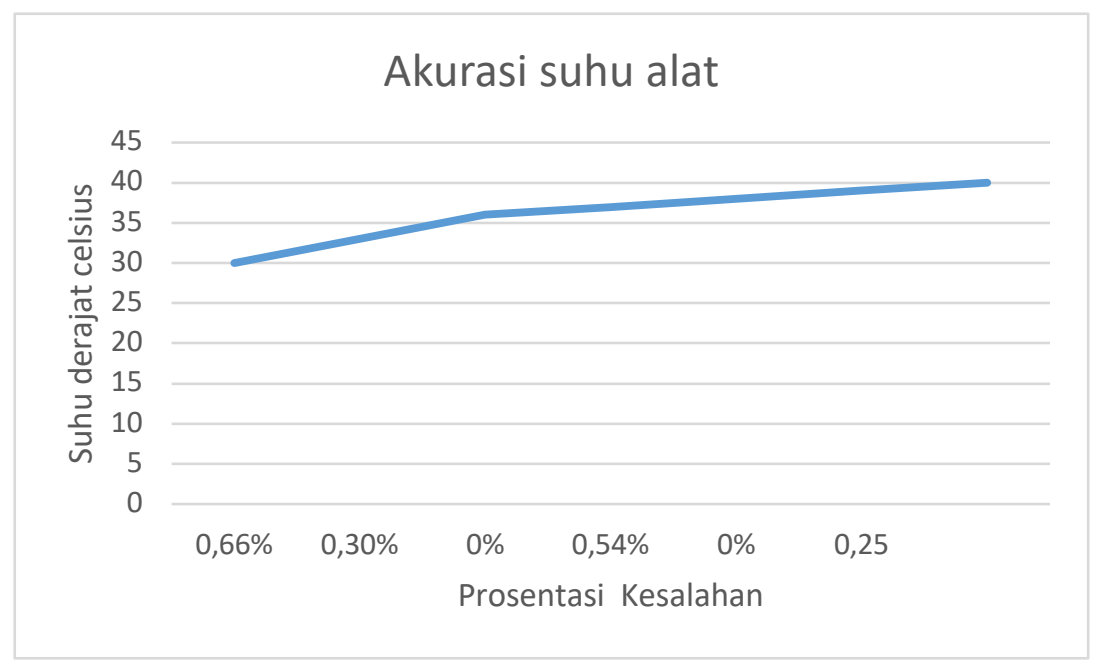

Gambar 5. Grafik Prosentasi Kesalahan

Pengukuran dilakukan pada suhu ruang tidak berpendingin dan tidak terpapar dengan sinar matahari langsung. Pengukuran dilakukan 7 kali pada suhu tubuh manusia. Perhitungan prosentase kesalahan dengan rumus absolut teori - ukur dibagi teori kali 100.

Dari hasil rancangan tersebut, alat pengukuran suhu tubuh non kotak dapat digunakan dengan baik dengan jarak antara alat dan obyek pengukuran $35-50 \mathrm{~cm}$ sehingga dapat menjaga jarak antara pemeriksa dengan obyek pengukuran (orang yang akan diukur suhunya) yang dapat meminimalkan risiko penularan Covid-19. Hasil ini berbeda dengan penelitian sebelumnya yang dilakukan Ardiyanto et.all, alat pengukur suhu tubuh yang dirancang memperoleh hasil pengukuran yang efektif jika jarak pengukuran antara alat dengan orang yang diukur 2-5 $\mathrm{cm}$. Pada penelitian tersebut menggunakan Arduino UNO R3 ATmega 328 [10]. Hasil rancangan penelitian lain yang dilakukan Safitri dan Dinata berupa alat pengukur suhu tubuh non kontak dengan menggunakan sensor inframerah yang sama dan mikrokontroler Ardiuno Nano, diperoleh hasil pengukuran yang efektif jika jarak pengukuran 1-2 cm [11]. Dari perbandingan tersebut menunjukkan bahwa alat hasil rancangan ini memiliki kelebihan yaitu jarak pengukuran antara alat pengukur suhu dengan orang atau obyek yang diukur lebih jauh yaitu $35-50 \mathrm{~cm}$.

Hasil pengukuran alat rancangan ini muncul dilayar berupa suhu dalam ${ }^{\circ} \mathrm{C}$ dan keterangan diagnosa apakah suhu hasil pengukuran tersebut menunjukkan normal, hipotermi atau hipertermi. Berbeda dengan alat rancangan Ardiyanto et.all, pada hasil pengukurannya tidak dilengkapi dengan keterangan yang menunjukkan apakah suhu normal atau tidak. Akan tetapi alat tersebut dilengkapi dengan alarm yang akan berbunyi jika hasil pengukuran melebihi $37,5^{\circ} \mathrm{C}[10]$.

Dibawah ini tampilan layar dari hasil pengukuran alat rancangan ini yang menunjukkan keterangan diagnosa hasil pengukuran sebagai berikut: 
Supriyanto, Wahyuning

Alat Pengukur Suhu Tubuh Non Kontak

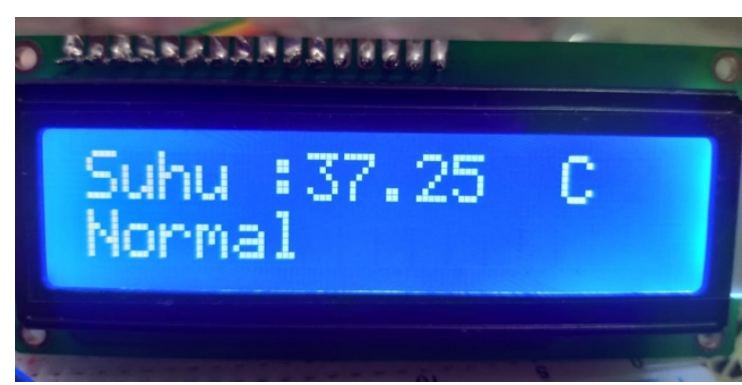

Gambar 6. Hasil Pengukuran Suhu Normal

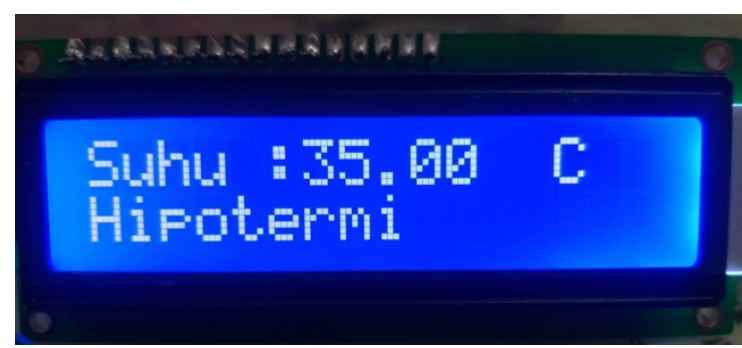

Gambar 7. Hasil Pengukuran Suhu Hipotermi

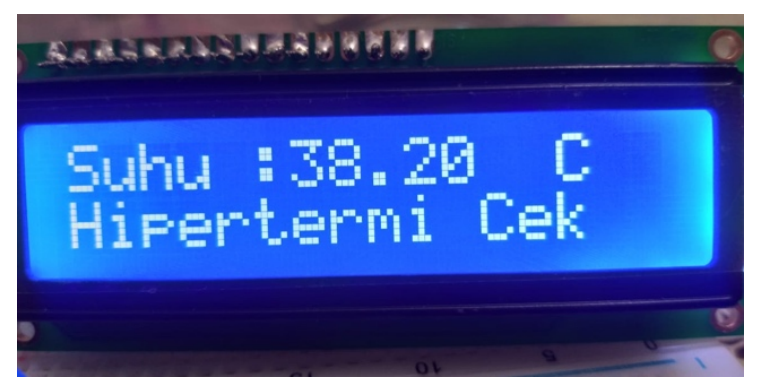

Gambar 8. Hasil Pengukuran Suhu Hipertermi

\section{KESIMPULAN}

Pembuatan alat pengukur suhu tubuh non kontak dapat bekerja dengan baik, mempunyai akurasi pengukuran $97,99 \%$. Pengukuran menggunakan alat non kontak diruangan berpendingin mempunyai pengaruh dalam pembacaan sensor ini. Baiknya pengukuran pada ruangan terbuka tanpa pendingin udara dan tidak terpapar dengan sinar matahari secara langsung. Prosentasi kesalahan $2,01 \%$ bisa dikurangi dengan kepresisian dalam mengkalibrasi alat ini. Hasil pengukuran yang efektif diperoleh dengan jarak antara alat pengukur suhu tubuh dan obyek yang diukur (manusia) 35$50 \mathrm{~cm}$.

\section{DAFTAR PUSTAKA}

[1] WHO, "WHO Corona virus (Covid 19)," 2020. [Online].

Available: https://covid19.who.int/.

[2] D. Handayani, H. D. Rendra, F. Isbaniah, B. Erlina, and H. Agustin, "No Title," J. Respirologi Indones., vol. 40, no. 2, pp. 119-129, 2020, [Online].

Available: https://jurnalrespirologi.org/index.php/jri/article/view/101/110.

[3] Kementerian Kesehatan Republik Indonesia, Pedoman Pencegahan dan Pengendalian Coronavirus Disease (Covid 19). Jakarta: Kemenkes RI, 2020.

[4] H. Santoso, Panduan Praktis Arduino untuk Pemula. Elangsakti.com, 2015.

[5] Arduino, "Microcontroller-ATmega328-328P_Datasheet," Arduino, 2018. https://store.arduino.cc/usa/arduino-uno-rev3. https://store.arduino.cc.

[6] Sudimanto, "Media Informatika Vol.18 No.1 (2019) 37," vol. 18, no. 1, pp. 37-41, 2019.

[7] P. Pauliano and B. Sumanto, "Pengukur Suhu Tubuh Secara Tak Sentuh Menggunakan Inframerah Berbasis Arduino Uno," Yogyakarta, 2014. [Online]. 


\section{Supriyanto, Wahyuning}

Alat Pengukur Suhu Tubuh Non Kontak

Available: http://etd.repository.ugm.ac.id/penelitian/detail/69359.

[8] Y. Mukhammad and A. S. Hyperastuty, "Sensitivitas Sensor MLX90614 Sebagai Alat Pengukur Suhu Tubuh Tubuh Non-Contact Pada Manusia," Indones. J. Prof. Nurs., vol. 1, no. 2, p. 51, 2021, doi: 10.30587/ijpn.v1i2.2339.

[9] Github, “Adafruit-MLX90614-Library.," Github, 2020. https://github.com/adafruit/Adafruit-MLX90614-Library.

[10] A. Ardiyanto et al., "Alat Pengukur Suhu Berbasis Arduino Menggunakan Sensor Inframerah Dan Alarm Pendeteksi Suhu Tubuh Diatas Normal," Sinusoida, vol. XXIII, no. 1, pp. 11-21, 2021.

[11] M. Safitri and G. A. Dinata, "Non-Contact Thermometer Berbasis Infra Merah," Simetris J. Tek. Mesin, Elektro dan Ilmu Komput., vol. 10, no. 1, pp. 21-26, 2019, doi: 10.24176/simet.v10i1.2647. 